\title{
Adapting sustainability and energy efficiency principles to architectural education: A conceptual model proposal for the design studio sequence
}

\author{
Salih Ceylan ${ }^{1, *}$ \\ ${ }^{1}$ Faculty of architecture and design, Bahçeșehir University, Istanbul, Turkey
}

\begin{abstract}
Architectural education is the first step into the professional career of an architect. It has strong connections with the profession itself regarding the technological trends and the needs of the society. Therefore, emerging challenges and developments in the world of architecture like environmental problems and sustainability issues need to be addressed by the educational programs of architecture. In addition to this, sustainable Development Goals (SDG) Program of United Nations puts an important responsibility on the shoulders of architectural educators. SDG includes both architectural and educational goals such as quality education, affordable and clean energy, sustainable cities and communities, and climate action. Accordingly, architectural education needs to be formed in a way to respond to the requirements of the contemporary global society. Design studio is the heart and core of architectural education. It is the place where all the theoretical and technical knowledge and skills gained in other courses become useful for the students to come up with design ideas and products. Additionally, design studios are not isolated environments. They form a series of courses by the consecutive repetition throughout the continuum of architectural education. Thus, they need to be treated as a developing sequence. Therefore, it is very important and valuable that the structure of the design studio sequence is improved and updated with suitable revisions towards emerging needs of the profession and society like the adaptation of sustainability principles, to reflect the dynamic character of architectural education itself. This paper presents a conceptual model proposal for the design studio sequence for the adaptation of sustainability principles to architectural education.
\end{abstract}

\section{Introduction}

Since ancient times, the practice of architecture and its products are affected from the environment they exist in. These effects can be taken physically in terms of conditions such as the accessibility of the material, topographic and geographical situation, climate, as well as in the sense of psychological, social and cultural influence. Rapoport [1] mentions that the form transformed into a structure is determined by cultural factors, and natural conditions have only a limited effect in this process. As a result of the effect of all these factors and conditions, the concept of architectural identity emerges. According to Hacihasanoğlu [2], architectural identity, as a sub-expansion of cultural and urban identity systems, interacts with city and conservation plans, architectural styles, architectural languages, building and environmental policies, materials and technology, behaviors and attitudes towards the environment. All architectural products that emerged throughout the history of humanity have revealed an identity belonging to the time, geography and culture they are in, and on the other hand, contributed to the formation of culture. This cycle has continued in this way from the first ages until the twentieth century without exceptions. In the early $1900 \mathrm{~s}$, changes began to emerge in the world order as a result of the industrialization process. Mass production takes the place of handwork, and gigantic factories take the place of small workshops. The rapid development in technology and communication facilities not only allowed events and developments to spread around the world in a short time, but also contributed to the replacement of traditional architectural movements by innovative trends like modern architecture which are based on technology and industrialization. Modern architecture has changed the course of architectural history both through its intellectual infrastructure and its expression in form, and has led to the first step to be taken in reconsidering the concept of "architectural identity".

Architecture is a profession that benefits from technology, follows the economy, and is affected by political events. Therefore, the profession and education of architecture are affected by emerging developments. Architecture has been developing with the globalization of technology, reaching everywhere in a short time, and obtaining information more easily wherever it is, and architectural products started to be similar to each other [3]. After the 1950 s, architecture in the world has started to be applied on a basis of technology and globalism. An important result emerged from this development is the increasing

\footnotetext{
* Corresponding author: salih.ceylan@arc.bau.edu.tr
} 
amount of resources and energy required in architectural and construction activities. The energy consuming structures required by the increased populations and living comfort standards, together with technological systems used in the buildings have exceeded the sustainable limits, especially since the late 20th century. According to the World Energy Council, global energy demand will increase until 2030 [18].

Today, the construction sector and its components, which is the most important application area of architecture, is the sector that has the largest share in the world's total energy use. $50 \%$ of the energy consumed worldwide, $50 \%$ of greenhouse gases that cause global warming, 24\% of air pollution, and $50 \%$ of CFC and HCFC emissions are due to activities related to buildings [4]. Therefore, any action within the architectural practice is expected to have a major impact on energy and environmental issues. Consequently, serious approaches to mitigate energy and resource use have been developed within the practice of architecture especially in the last 40 years.

Sustainability is an urgent theme for humanity. The responsibility of architecture about sustainability and energy efficiency problems is emphasized in the Sustainable Development Goals Program of the United Nations as well, considering that many of the goals are directly or indirectly related with architecture [8]. Especially goal number 7, affordable and clean energy, and goal number 11, sustainable cities and communities shall be considered under the responsibility of architecture profession. To contribute to the achievement of these goals, and to provide more sustainable built environments, architecture profession needs to fulfill its responsibilities towards the society. But firstly, these responsibilities and strategies to overcome the energy and resource problems must be clarified, and architects need to be made aware of the situation. Considering the strong connection between the profession and education of architecture and that both are affecting and being affected from each other, the process of awareness most effectively starts in the education period. Consequently, increasing environmental problems and sustainability issues need to be initial elements of architectural education so that it can contribute to the profession to stay up-to-date.

\section{Sustainability and architectural education}

Education is a powerful agent that raises awareness for emerging developments and contributes to social change [12]. The profession of architecture is a special field that differs from other professions in terms of its prominent features at the education stage. Unlike other fields of science, architectural education requires the students to work with all their senses and emotions. In architectural education, the ability of the mind, eye and hand to work together should be developed [5]. According to Cook, the most enjoyable and at the same time most disturbing aspect of architecture is its open-endedness, which is a mixture of measurable and immeasurable features [6]. The transfer of knowledge and experience in architecture can only be carried out in a healthy way with a mutual interaction between the educator and the student. The rapid development and change seen in today's world of architecture requires a rapid change in architectural education as well. Therefore, it is an important step to be taken by the institutions providing architectural education to design their programs and contents in such a way that they can be changed and updated frequently, to ensure the continuity of education and its competence in meeting professional needs.

It is assumed that environmental and energy problems, and therefore energy efficiency and sustainability concepts in design will continue to have the importance they have today, and will even become more critical in the upcoming years. Therefore, energy efficient design is not a temporary architectural trend, but a design approach that should be permanently embedded in architectural practice. It is necessary that mandatory requirements of sustainability is a core issue for the formation of professional competence [13]. The training of architects who will implement this approach is only possible if they recognize and apply this approach during their education. Architectural education has great responsibility in the training of young architects who are aware and capable of solving environmental problems [11]. Architectural education is failing to respond to the rapid changes in the world [9]. Architects should have more knowledge, competence and awareness about energy efficiency and sustainability than anyone else. UIA [14] states that architectural education is expected to prepare architects to bear the responsibility for the health, safety, welfare and cultural interests of the public and for the sustainability of the built environment. Accordingly, sustainability principles need to be implemented into the architectural education curriculum as fundamental elements. The concerns about sustainability of the built environment and the sustainability of the society are important aspects of architectural education [15]. However, this is a complex process, including theory and practice-based interdisciplinary knowledge [10]. The issue about which phases and which sections of the curriculum these principles are supposed to be inserted into is a question of curriculum design. The curriculum needs to be revised and developed by the adaptation of sustainability principles to the relevant and suitable points.

Contemporary architectural education can be divided into 4 main categories: In the first category, there are courses that form the theoretical and conceptual foundations of architecture as in the second category, the concepts that constitute the technical infrastructure of architecture are taught; in the third category courses that develop presentation and expression techniques are; and in the fourth category there are studio lessons in which the lessons learned in the other three categories are applied by bringing them together [7]. Therefore, the implementation of sustainability principles may happen at various courses or course groups, but as the heart and core of architectural education, the design studio is the most suitable place to create connections between design issues and sustainability. 


\subsection{The importance of the design studio}

The common aspect of architectural education in all institutions is that it is a branch that advocates learning by practicing. Studios are the places where the practice in architectural education happens most effectively. Design studio is the environment where the students learn various ways of design and nourish their creativity [16]. In the design studio, students learn different aspects of design education such as visualization and architectural thinking [17]. While theoretical, technical or practical information is given to students in all courses, studios are the place where all this information is brought together and the acquired skill is transformed into a product. Studio courses have the greatest weight in the curriculum of all architectural education institutions. The studio lessons, which continue regularly from the first semester of architectural education to the end, are the most important factors that shape the student's view and style of architecture throughout his/her education life. In this context, the content of architectural design or studio courses should be examined and prepared very well, both as a single course and as a series of courses. While planning the curriculum as a whole, the general structure of the architectural project series should be established, and the scope and subjects of the successive studios should be fictionalized within a certain context. It is important that the topics, plots and systems in question are not repetitive, but complement each other. The individual contents of the project courses should also be created in accordance with the general framework, including the information and practices that the student will need according to the level she/he is in. Since the project course environment is an environment where the lecturer and the students are in direct contact, it is also important that these courses are designed in a way that makes it possible to be personalized. In terms of energy efficient design approach, studios draw attention as the most suitable application areas. It should be among the objectives of the design courses that many different topics, from the basic principles of energy efficient design to the latest technological applications and technical details, are handled in the studios and that various applications that provide energy efficiency are integrated into the design by the student. Which energy efficient application will be used in which periods and in what kind of projects and how it will be adapted to the design are also important issues to be decided during the design of the studio sequence and the preparation of the curriculum.

Design studio courses are the most suitable parts of architectural education regarding the adaptation of sustainability principles. However, the studio courses need to be considered as a complete sequence from first to the last year of education, instead of producing independent solutions for each studio separately. It should be taken into consideration that the coordination of the studios is important to hinder repetitive, irrelevant, and incomplete attempts.

\section{A conceptual model proposal for the design studio sequence}

Adapting sustainability and energy efficiency principles to architectural education is an important issue for the future of architecture profession. Accordingly, the implementation needs to be executed firmly. The design studios are appropriate courses to be the first steps of a revision of this kind because they are flexible and open for customization. Each design studio is unique and has its own character and requirements. However, within the frame of the curriculum, all design studios must be connected with each other within a context. This study evaluates the design studio sequence as a continuous structure, and proposes a holistic conceptual model for the whole sequence. Therefore, the definitions for each design studio are open to interpretation. Following chapter presents the specifications for each design studio from first to the last year of education.

\subsection{Details of the proposed model}

Adapting sustainability and energy efficiency principles to architectural education is an important issue for the future of architecture profession. Accordingly, the implementation needs to be executed firmly. The design studios are appropriate courses to be the first steps of a revision of this kind because they are flexible and open for customization. Each design studio is unique and has its own character and requirements. However, within the frame of the curriculum, all design studios must be connected with each other within a context. This study evaluates the design studio sequence as a continuous structure, and proposes a holistic conceptual model for the whole sequence. Therefore, the definitions for each design studio are open to interpretation. Following chapter presents the specifications for each design studio from first to the last year of education.

\subsubsection{First semester design studio}

The design studio in the first semester is mostly considered as an introduction to architectural practice. It is the first design experience of the students, so that the structure of the studio needs to be kept simple but effective. The architectural program of the design problem shall be very simple, consisting of a single space or volume with only a natural environment in the surroundings. The size of the construction area might be up to 50 square meters, and the emphasized sustainability element shall be orientation and relationships with the land and topography.

\subsubsection{Second semester design studio}

In the second semester of their educations, students are still in their freshman year, and their introduction to architecture continues. In the design studio, the basic definitions of design shall be emphasized. The architectural program shall be a simple one with a singular function, and the context shall be natural or rural 
environment with low density. The structure can be between 50 and 200 square meters, and the sustainability applications can focus on the relations between indoor and outdoor spaces, and passive systems like natural ventilation and daylight use.

\subsubsection{Third semester design studio}

In the third semester, the design studio shall become relatively complicated. Architectural program is still low in complexity with a basic function like residential or commercial purposes. Environmental context shall be an urban area with low density, and the area of construction can be between 200 and 500 square meters. The sustainability applications emphasized in this studio are simple insulation and indoor environmental quality issues.

\subsubsection{Fourth semester design studio}

Architectural program gets more complicated in the fourth semester, considering two interconnected actions like working and residing together. The building size shall be between 500 and 1000 square meters, and the surrounding area shall be an urban space with average density. The sustainability applications proposed for this studio are artificial lighting, artificial ventilation and recycled materials.

\subsubsection{Fifth semester design studio}

Fifth semester design studio deals with a more complicated design problem like a local public building in an urban area with high density. The total construction area in this design studio can be between 1000 and 2000 square meters, and the related energy efficiency concerns are focused on green roofs and rainwater management.

\subsubsection{Sixth semester design studio}

In the sixth semester, the architectural program gets complex through a mixed-use building that most possibly consists of multiple floors. The environment around the building may be a special urban area, probably one with a historic value. The total construction area is 2000 to 3000 square meters, as the sustainability applications are focused on acoustic solutions, wastewater management, and solid waste management.

\subsubsection{Seventh semester design studio}

Seventh semester design studio deals with a complicated design problem with a unique function that requires specialization like education or healthcare. The context is urban with high density, and the total construction area is supposed to be between 3000 and 6000 square meters. Related energy efficiency applications in this design studio are focused on alternative and sustainable energy production, and energy efficient façade design.

\subsubsection{Eighth semester design studio}

Eighth semester is the last one of the proposed architectural curriculum, and the design studio shall reflect the advanced level the students have reached at the end of their education. The architectural program in this design studio represents a public building with multiple functions. The context of this design studio consists of an urban environment with high density and special features, and the total required construction area is between 6000 and 10000 square meters. Sustainability applications in this design studio are smart building systems, life-cycle cost analysis and optimization, and sustainable construction methods.

Table 2. The proposed design studio sequence.

\begin{tabular}{|c|c|c|c|c|}
\hline $\begin{array}{c}\text { Studio } \\
\text { Course \# }\end{array}$ & $\begin{array}{c}\text { Architectural } \\
\text { Program }\end{array}$ & $\begin{array}{c}\text { Environmental } \\
\text { Context }\end{array}$ & Area & $\begin{array}{c}\text { Sustainability } \\
\text { applications }\end{array}$ \\
\hline $\begin{array}{l}\text { Design } \\
\text { Studio } 1\end{array}$ & $\begin{array}{l}\text { Single volume } \\
\text { with a sole } \\
\text { function }\end{array}$ & $\begin{array}{c}\text { Simple natural } \\
\text { environment }\end{array}$ & $\begin{array}{l}\text { Up to } \\
50 \mathrm{~m}^{2}\end{array}$ & $\begin{array}{l}\text { Orientation, } \\
\text { land and } \\
\text { topography } \\
\text { relations }\end{array}$ \\
\hline $\begin{array}{c}\text { Design } \\
\text { Studio } 2\end{array}$ & $\begin{array}{l}\text { Simple program } \\
\text { with a single } \\
\text { function }\end{array}$ & $\begin{array}{l}\text { Natural or rural } \\
\text { environment with } \\
\text { low density }\end{array}$ & $\begin{array}{l}50 \text { to } \\
200 \\
\mathrm{~m}^{2}\end{array}$ & $\begin{array}{c}\text { Natural } \\
\text { ventilation, } \\
\text { daylight use, } \\
\text { indoor-outdoor } \\
\text { relations }\end{array}$ \\
\hline $\begin{array}{l}\text { Design } \\
\text { Studio } 3\end{array}$ & $\begin{array}{l}\text { Single program } \\
\text { with a basic } \\
\text { function }\end{array}$ & $\begin{array}{l}\text { Urban } \\
\text { environment with } \\
\text { low density }\end{array}$ & $\begin{array}{c}200 \\
\text { to } \\
500 \\
\mathrm{~m}^{2} \\
\end{array}$ & $\begin{array}{c}\text { Basic } \\
\text { insulation, } \\
\text { indoor } \\
\text { environmental } \\
\text { quality } \\
\end{array}$ \\
\hline $\begin{array}{c}\text { Design } \\
\text { Studio } 4\end{array}$ & $\begin{array}{l}\text { Combination of } \\
\text { two } \\
\text { interconnected } \\
\text { functions }\end{array}$ & $\begin{array}{l}\text { Urban } \\
\text { environment with } \\
\text { medium density }\end{array}$ & $\begin{array}{c}500 \\
\text { to } \\
1000 \\
\mathrm{~m}^{2}\end{array}$ & $\begin{array}{c}\text { Artificial } \\
\text { lighting, } \\
\text { artificial } \\
\text { ventliation, } \\
\text { recycled } \\
\text { materials } \\
\end{array}$ \\
\hline $\begin{array}{l}\text { Design } \\
\text { Studio } 5\end{array}$ & $\begin{array}{c}\text { Moderately } \\
\text { complex } \\
\text { program with a } \\
\text { public function }\end{array}$ & $\begin{array}{l}\text { Urban } \\
\text { environment with } \\
\text { high density }\end{array}$ & $\begin{array}{c}1000 \\
\text { to } \\
2000 \\
\mathrm{~m}^{2} \\
\end{array}$ & $\begin{array}{l}\text { Green roofs, } \\
\text { rainwater } \\
\text { management }\end{array}$ \\
\hline $\begin{array}{c}\text { Design } \\
\text { Studio } 6\end{array}$ & $\begin{array}{l}\text { Complex } \\
\text { program for } \\
\text { mixed-use } \\
\text { functions }\end{array}$ & $\begin{array}{l}\text { Urban } \\
\text { environment with } \\
\text { historical value }\end{array}$ & $\begin{array}{c}2000 \\
\text { to } \\
3000 \\
\mathrm{~m}^{2}\end{array}$ & $\begin{array}{c}\text { Acoustics, } \\
\text { wastewater } \\
\text { management, } \\
\text { solid waste } \\
\text { management } \\
\end{array}$ \\
\hline $\begin{array}{c}\text { Design } \\
\text { Studio } 7\end{array}$ & $\begin{array}{c}\text { Complex } \\
\text { program with } \\
\text { unique function }\end{array}$ & $\begin{array}{l}\text { Urban } \\
\text { environment with } \\
\text { high density }\end{array}$ & $\begin{array}{c}3000 \\
\text { to } \\
6000 \\
\mathrm{~m}^{2}\end{array}$ & $\begin{array}{c}\text { Alternative } \\
\text { energy } \\
\text { production, } \\
\text { energy efficient } \\
\text { façades } \\
\end{array}$ \\
\hline $\begin{array}{c}\text { Design } \\
\text { Studio } 8\end{array}$ & $\begin{array}{l}\text { Complex } \\
\text { program for a } \\
\text { public building } \\
\text { with various } \\
\text { functions }\end{array}$ & $\begin{array}{c}\text { Urban } \\
\text { environment with } \\
\text { high density and } \\
\text { special features }\end{array}$ & $\begin{array}{c}6000 \\
\text { to } \\
10000 \\
\mathrm{~m}^{2}\end{array}$ & $\begin{array}{l}\text { Smart building } \\
\text { systems, life- } \\
\text { cycle cost } \\
\text { analysis and } \\
\text { optimization, } \\
\text { and sustainable } \\
\text { construction } \\
\text { methods }\end{array}$ \\
\hline
\end{tabular}

The proposed design studio sequence is continuous, and each studio builds upon and develops the one that comes before (See Table 1). The architectural program starts with a single volume and gets more complicated in the upcoming studios, the environmental context gets denser and complex, and constructed area gets gradually bigger each semester. Accordingly, applications about sustainability and energy efficiency also start from simple and basic ones in the first semesters, and they get more technical, complicated, and technology-based in the advanced semesters. Consequently, the proposed design studio sequence covers a wide perspective of sustainability and energy efficiency approaches. However, it must be not forgotten that the design studio courses are not alone in the curriculum, and must be supported with 
theoretical and technical courses that answer to the questions revealed in the relevant design studios.

\section{Conclusion}

Architectural education is a multidimensional and multicomponent process. Energy efficient design has recently started to be included in these training programs as an important component and it is predicted that this situation will not change in the future. In this context, it is an undeniable fact that architectural education should be redesigned to include an energy efficient design approach. It is important to ensure the continuity of education that this redesign is carried out not as an action that can be done in a single step, but as a planned process that spans a certain time. In addition, taking into account the factors depending on the place and time will ensure that this process works in a healthy way. Existing architectural, educational and social conditions have led to the process of adapting energy efficient design principles to architectural education to progress more slowly and without determination. However, it is seen that it is possible to accelerate this process and make it healthy and holistic with the measures to be taken and the practices to be made.

The approach of using the design studio sequence as the focal point for the implementation sustainability principles into the architectural education is an effective one. However, this operation requires expertise and strong collaboration among education curriculum designers. Design studio educators, students, and all other stakeholders of the design studio need to be a part of this process, to eventually come up with a structure that responds to the needs of students and educators, and the requirements of the emerging professional medium at the same time.

The proposed model is conceptual and creates a general frame for the design studio sequence. For more concrete implementations, the local factors for the architecture and education of the region or country must be considered. Accordingly, revisions and improvements for better adaptation might be required as well.

This study is purely focused on the design studio sequence as the revisions in other technical and theoretical courses are not considered. Even though this study provides a lot of information and knowledge about the possibilities for the improvement of the architectural education curriculum, for better and more holistic results, all courses must be considered as a whole. The interaction between design studios and other courses shall ensure a more effective result in terms of the desired objectives regarding the implementation of sustainability principle into architectural education.

This paper and similar studies that aim to provide connections between architectural education and sustainability are important and beneficial for creating a framework of the problem. However, to be more effective and sufficient, these studies need to increase in numbers and become more realistic through experience-based case studies, together with other empirical and statistical implementations concerned about the same or similar research subjects.

\section{References}

1. A. Rapoport, House Form and Culture (Prentice-Hall inc., New Jersey, 1964)

2. O. Hacıhasanoğlu, Multi-Functional Space Organization: A Comparison Of Traditional And Squatter Houses In Turkey, Open House International, 22, 87-93 (1997).

3. H. Nalçakan, Ç. Polatoğlu, Türkiye'deki ve Dünyadaki Mimarlık Eğitiminin Karşılaştırmalı Analizi ile Küreselleşmenin Mimarlık Eğitimine Etkisinin İrdelenmesi (Education Of Architectural In World And Turkey With Comparison Analyses And The Effect of The Globalisation To The Architectural Education), Megaron, 3 79-103 (2008)

4. D. Eryıldız, Sürdürülebilirlik ve Mimarlık Dosyasında Ekolojik Mimarlık (Ecological architecture in the folder of sustainability and architecture), Arradamento Architecture, 154, 71-75 (2003)

5. J.N. Erzen, Eğitimin Estetik Süreç Olarak Yorumu ve Mimarlık Eğitimi (Interpretation of education as a process and architectural education), Journal of METU Faculty of Architecture, 2, 175-185 (1976)

6. P. Cook, Primer (Academy Editions, Londra, 1996)

7. B. Uluoğlu, Mimari Tasarım Eğitimi: Tasarım Bilgisi Bağlamında Stüdyo Eleştirileri, Ph.D. thesis, İTÜ, İstanbul, Turkey (1990)

8. United Nations, Sustainable Development Goals, available at: https://sdgs.un.org/goals (2015)

9. X. Xiang, X. Yang, J. Chen, R: Tang, L. Hu, A Comprehensive Model of Teaching Digital Design in Architecture that Incorporates Sustainability, Sustainability 12, 1-29 (2020)

10. J. Jablonska and S. Ceylan, Sustainable architecture in education, World Transactions on Engineering and Technology education 19, 96-101 (2021)

11. S. Ceylan, Students' approach to recycling and sustainability: A design study on affordable container houses, in: J. Charytonowicz (ed.), Advances in Human Factors in Architecture, Sustainable Urban Planning and Infrastructure, 175-181, Springer, New York (2020)

12. M. Taleghani, H.R. Ansari, P. Jennings, 2011, Sustainability in architectural education: A comparison of Iran and Australia. Renewable Energy, 36, 2021-2025 (2010)

13. S. Altomonte, Environmental education for sustainable architecture, Review of European Studies, 1, 12-21 (2009)

14. UIA, Architectural Education Reflections and Recommendations, International Union of Architects, Paris (2002)

15. S. Ceylan and M. Soygeniş, design studio experience: impacts of social sustainability, Archnet-IJAR 
International Journal of Architectural Research, 13, 368-385 (2019)

16. S. Ceylan, P. Şahin, S. Seçmen, M.E. Somer, K.H. Süher, An evaluation of online architectural design studios during COVID-19 outbreak, Archnet-IJAR International Journal of Architectural Research, 15, 203-218 (2021)

17. S. Ledewitz, Models of design in studio teaching, Journal of Architectural Education, 38, 2-8 (1985)

18. R. Davies, Global demand for energy will peak in 2030 says World Energy Council, The Guardian, available at :

https://www.theguardian.com/business/2016/oct/10/ global-demand-for-energy-will-peak-in-2030-saysworld-energy-council (2016) 